Computer Based Information System Journal

\title{
SISTEM PENDUKUNG KEPUTUSAN PENENTUAN PENILAIAN SISWA DENGAN METODE SAW (SIMPLE ADDITIVE WEIGHTING)
}

\author{
Suwarno Liang1), Muhammad Romi Muhtarom ${ }^{2)}$ \\ Universitas Internasional Batam, Indonesia.
}

\section{INFORMASI ARTIKEL}

Diterima Redaksi: 26 Januari 202

Diterbitkan Online: 24 Maret 2021

\section{KATA KUNCI}

Simple additive weighting, Sistem

Pendukung Keputusan, PHP, Laravel

\section{KORESPONDENSI}

suwarno.liang@uib.ac.id

mromimuhtarom28@gmail.com

\section{A B S S T $\mathbf{R}$ A $\mathbf{C}$ T}

Penilaian hasil belajar siswa merupakan salah satu proses yang wajib ada pada lembaga pendidikan, baik itu lembaga pendidikan formal ataupun non-formal dengan tujuan untuk memantau dan mengevaluasi perkembangan siswa selama proses pembelajaran berlangsung. Seiring dengan perkembangan teknologi yang semakin maju, tentunya ada banyak proses yang dapat diintegrasikan dengan teknologi informasi dengan tujuan untuk mempermudah proses yang telah ada, dan proses penilaian hasil belajar siswa bukanlah pengecualian. Tujuan dari penelitian ini adalah untuk memberikan kemudahan bagi guru dalam membuat keputusan terhadap hasil proses penilaian hasil belajar siswa dengan menggunakan beberapa atribut yang telah ditentukan. Atribut yang digunakan sebagai bahan acuan pertimbangan yaitu tugas, UTS dan UAS. Dengan begitu penelitian ini dibuat dengan menggunakan framework Laravel dan bahasa pemrograman PHP serta metode Simple Additive Weighting (SAW) yang merupakan salah satu metode pendukung keputusan untuk membantu penyelesaian permasalahan yang kompleks. Luaran dari penelitian ini adalah sebuah sistem informasi yang mampu menunjang keputusan penilaian hasil belajar siswa dalam bentuk peringkat siswa, dan memberikan transparansi serta kemudahan bagi siswa untuk mengakses nilai ataupun hasil akhir dari proses penilaian hasil belajar siswa. 


\section{Latar Belakang}

Dalam kehidupan sehari-hari, manusia sering mengalami kesulitan dalam menentukan keputusan yang tepat pada sebuah permasalahan. Besar atau kecil suatu permasalahan sangat berpengaruh terhadap hasil dari keputusan tersebut. Keputusan yang tidak tepat tentunya akan membawa dampak buruk berupa kerugian baik itu secara langsung ataupun tidak langsung.

Perkembangan teknologi sendiri sudah semakin maju. Sudah tidak menjadi rahasia bahwa perkembangan tersebut telah menghasilkan banyak teknologi-teknologi baru yang memiliki tujuan untuk mempermudah ataupun menyelesaikan masalah yang dihadapi oleh manusia. Salah satu dari teknologi tersebut adalah teknologi sistem pendukung keputusan yang berfungsi untuk membantu manusia dalam menentukan keputusan dalam sebuah permasalahan.

Sistem pendukung keputusan sendiri merupakan sistem yang diharapkan dapat membantu memberikan rekomendasi keputusan kepada pengguna untuk membina yang berdasarkan data yang telah disimpan, serta dapat membantu yang bersangkutan untuk menetapkan langkah ataupun keputusan yang akan diambil berdasarkan data yang tersedia [1]. Dalam menerapkan sistem pendukung keputusan, terdapat beberapa metode yang dapat dipertimbangkan, salah satunya adalah metode Simple Additive Weighting (SAW) [2]. Metode SAW merupakan salah satu metode yang paling banyak digunakan dalam menerapkan sistem pendukung keputusan dikarenakan metode ini memiliki pendekatan penyelesaian masalah berupa Multi Attribute Decision Making (MADM) yang sederhana [3]. Konsep metode ini berdasarkan kepada bobot kriteria sebagai acuan penilaian untuk diproses ke dalam algoritma ini.

Sistem pendukung keputusan memiliki peran yang besar diberbagai bidang, tidak terkecuali di bidang pendidikan. Di bidang pendidikan, penggunaan sistem pendukung keputusan sendiri telah banyak diimplementasi, sebagai contoh adalah sekolah SMK Bumi
Nusantara Wonosobo menerapkan sistem pendukung keputusan untuk pemeringkatan calon siswa baru melalui jalur undangan [4]. Tentunya penerapan teknologi berupa sistem pendukung keputusan dapat memberikan dampak positif untuk memudahkan proses bisnis pada lembaga pendidikan. Walaupun begitu, masih ada beberapa institusi lembaga pendidikan yang belum menerapkan teknologi dan masih menggunakan metode tradisional dalam melakukan proses bisnis tertentu, di mana salah satu dari proses bisnis tersebut adalah proses penilaian hasil belajar siswa. Proses penilaian hasil belajar siswa sendiri merupakan sebuah proses yang bertujuan untuk mengetahui kemampuan siswa serta untuk meningkatkan prestasi dalam pembelajaran [5]. Apabila proses bisnis tersebut dilakukan dengan metode tradisional, seorang guru tentunya membutuhkan tambahan waktu untuk memproses data-data nilai dari siswa yang jumlahnya tidak sedikit. Selain itu, jika terjadi kesalahan ataupun human error seperti kesalahan dalam penginputan peringkat mata pelajaran, maka guru tersebut harus mengubah urutan pemeringkatan dan harus mencetak ulang rapor siswa yang mengakibatkan meningkatnya penggunaan kertas yang tentunya tidak ramah lingkungan.

Di wabah pandemi saat ini telah berdampak di seluruh dunia termasuk di Indonesia, sejak kuartal pertama 2020 telah banyak mengubah sistem pendidikan. Aktivitas pendidikan yang semula diadakan dengan cara tatap muka harus diubah menjadi pembelajaran jarak jauh di mana tujuannya sendiri adalah untuk mencegah penularan corona virus 2019 atau biasa disebut dengan COVID-19. Pencegahan ini juga merupakan salah satu dari program pemerintah yang diatur oleh KEMENDIKBUD dengan dikeluarkannya sebuah surat edaran Nomor 3 tahun 2020 tentang pencegahan COVID-19 pada satuan pendidikan dan Nomor 
36926/MPK.A/HK/2020 tentang pembelajaran online [6].

Penelitian ini dibuat dengan tujuan untuk meminimalisasi kesalahan dalam pemeringkatan mata pelajaran sebagai bahan evaluasi sekolah, mengurangi pemakaian penggunaan kertas sehingga pihak sekolah dapat menghemat biaya pengeluaran untuk pembelian kertas dan sekaligus menjaga lingkungan, mendukung program pemerintah dalam rangka mencegah terjadinya virus COVID-19 dengan cara memberikan kemudahan bagi siswa untuk mengakses nilai di mana saja dan kapan saja tanpa harus bertatap muka, meningkatkan efisiensi waktu bagi guru untuk menganalisis data dengan adanya penerapan sistem pendukung keputusan sebagai bahan pertimbangan.

Berdasarkan latar belakang dan informasi yang telah disampaikan sebelumnya, penulis ingin menciptakan sebuah solusi yang dapat diterapkan pada proses bisnis berupa penilaian hasil belajar siswa dengan membuat sistem pendukung keputusan yang dibuat menggunakan metode SAW dan bahasa pemrograman berbasis web yaitu PHP yang didukung dengan framework Laravel.

\subsection{Literatur Review}

\section{Kajian Literatur}

Berikut beberapa literatur review yang dapat disimpulkan dari penelitian sebelumnya yaitu:

a. Penelitian yang dilakukan oleh Sari [7] dengan judul "SPK Seleksi Penerimaan Guru Baru pada Yayasan Garis Pena Payakumbuh Menggunakan Metode SAW". Dalam penelitian ini membahas permasalahan tentang proses penerimaan calon guru honor yang begitu lama karena tidak tersambung secara terkomputerisasi, serta kesulitan kepala sekolah untuk memutuskan guru honorer untuk diangkat jadi guru tetap. Untuk mengatasi masalah tersebut penelitian ini membuat sistem pendukung keputusan untuk pengangkatan guru tetap dengan menerapkan metode
SAW sebagai pemeringkatan calon guru tetap yang dapat membantu pihak sekolah dalam mengevaluasi dari hasil kinerja guru baru. Sistem ini dijadikan bahan pertimbangan dalam keputusan, serta menerapkan pemberian nilai bobot pada setiap kriteria dalam penerimaan guru. Kriteria yang menjadi bahan pertimbangan adalah tingkat kesarjanaan ijazah, Indeks Prestasi Kumulatif (IPK), memiliki ilmu didaktik dan metodik, pengalaman mengajar, usia dan jarak tempat tinggal dengan sekolah.

b. Penelitian yang dilakukan oleh Asnawi \& Baihaqy [8] dengan judul "Implementasi Metode Simple Additive Weight (SAW) pada Sistem Pendukung Keputusan Penentuan Dosen Berprestasi”. Penelitian ini membahas sering terjadi permasalahan dalam pemberian nilai dosen prestasi dikarenakan banyaknya kriteria yang dinilai. Dengan begitu penelitian ini membuat sistem pendukung keputusan dengan menerapkan algoritma Simple Additive Weighting yang dapat membantu pihak penilaian dosen prestasi untuk memilih dosen berprestasi di Universitas Sains AlQuran. Tujuan dari penelitian ini adalah mengurangi kesalahan dalam proses perhitungan penilaian yang mengakibatkan kesalahan dalam urutan pemeringkatan dosen berprestasi.

c. Penelitian yang dilakukan oleh Ismanto \& Effendi [9] dengan judul "Sistem Pendukung Keputusan Penerimaan Karyawan dengan Metode Simple Additive Weighting (SAW)". Permasalahan yang dihadapi dalam penelitian ini adalah sering terjadi penilaian yang tidak subjektif dan nepotisme dalam penilaian. Dalam penilaian terdapat birokrasi yang berbelit-belit sehingga perekrutan karyawan menjadi lebih lama dari waktu yang seharusnya dibutuhkan. Untuk mengatasi masalah tersebut penelitian ini membuat sistem pendukung keputusan penerimaan 
karyawan. Tujuan dalam penelitian ini adalah dengan adanya Simple Additive Weighting (SAW) dapat menyelesaikan permasalahan birokrasi dalam pemilihan dan metode ini memiliki prioritas atau bobot yang ditentukan setiap kebutuhan. Semakin banyak alternatif dan penggunaan kriteria yang lebih spesifik dapat menghasilkan nilai dari proses penyeleksian yang lebih akurat. Algoritma ini dapat mendukung keputusan dalam hal penerimaan karyawan dengan memberikan pemeringkatan alternatif yang sesuai.

d. Penelitian yang dilakukan oleh Simarmata, Limbong, Aritonang \& Sriadhi [10] dengan judul "Sistem Pendukung Keputusan Pemilihan Guru Bidang Studi Komputer Menggunakan Metode Simple Additive Weighting (SAW)". Permasalahan yang terjadi dalam penelitian ini adalah pihak sekolah masih menggunakan metode secara manual dengan data langsung tanpa ada pertimbangan dari kriteria yang harus dipenuhi. Untuk mengatasi masalah tersebut penelitian ini membuat sistem pendukung keputusan. Tujuan dalam penelitian ini dapat mengurangi kesalahan dalam penilaian karena tidak ada pertimbangan atas kriteria yang dipenuhi.

e. Penelitian yang dilakukan oleh Aisyah [11] dengan judul "Aplikasi Sistem Pendukung Keputusan Analisis Kelayakan Pemberian Kredit Menggunakan Metode SAW pada Perusahaan Leasing". Permasalahan yang terjadi dalam penelitian ini adalah sering terjadi kesalahan dalam menganalisa untuk pemberian kredit kepada pelanggan, sehingga dapat merugikan dan menghambat kemajuan perusahaan. Dengan adanya sistem pendukung keputusan dapat membantu perusahaan tersebut untuk menganalisa kemampuan membayar calon nasabah, membantu proses penilaian kelayakan pemberian kredit dengan metode SAW. Penggunaan ini dapat disesuaikan dengan nilai bobot dari masing-masing kriteria, serta dapat memberikan rating dari hasil kinerja setiap alternatif pada semua atribut.

Dari 5 (lima) penelitian yang telah dipaparkan, penulis membuat sistem penilaian siswa dengan mengimplementasikan metode SAW dengan tujuan mengurangi kesalahan dalam proses perhitungan penilaian yang mengakibatkan kesalahan dalam urutan pemeringkatan [8], menyelesaikan masalah birokrasi dalam hal penilaian [9], mengurangi kesalahan penilaian dikarenakan tidak ada pertimbangan atas kriteria [10], membantu pihak sekolah dalam mengevaluasi penilaian [7] dan penggunaan metode SAW dapat memberikan rating dari hasil kinerja setiap alternatif pada semua atribut [11].

\subsection{Landasan Teori}

\subsubsection{Sistem Pendukung Keputusan}

Sistem pendukung keputusan merupakan sistem yang dapat mengurangi permasalahan yang tidak terstruktur sehingga memberikan informasi yang dapat dipakai untuk pengambilan keputusan [12]. Sistem pendukung keputusan memiliki alternatif yang harus diambil berdasarkan kriteria sebagai bahan pertimbangan [13].

Menurut Windarto [14] tahapan dalam pengambilan keputusan yaitu :

1. Mengidentifikasi masalah.

Dalam tahapan ini dilakukan analisa permasalahan yang terjadi. Identifikasi masalah merupakan proses pengenalan terhadap suatu masalah. Untuk menentukan sebuah masalah harus melewati dari observasi atau pengamatan di lapangan.

2. Pemilihan metode.

Pemilihan metode disesuaikan dengan permasalahan yang dapat diaplikasikan, serta pengetahuan aturan yang dapat menyelesaikan masalah. Metode dalam sistem pendukung keputusan diciptakan sebagai proses untuk mencapai sebuah tujuan.

3. Pengumpulan data. 
Pengumpulan data disesuaikan dengan metode yang akan diterapkan ke dalam sistem pendukung keputusan. Data didapatkan setelah melakukan analisa masalah dan pemilihan metode yang tepat.

4. Implementasi metode

Setelah mendapatkan data yang diperlukan, selanjutnya melakukan proses data tersebut yang disesuaikan dengan metode yang akan dipakai.

\section{Evaluasi sisi positif dari alternatif}

Setelah data diproses saat di tahap implementasi metode. Dari hasil tersebut diambil sisi positif sebagai bahan pertimbangan dalam pengambilan keputusan.

6. Melaksanakan solusi terpilih

Setelah mendapatkan hasil evaluasi dari proses metode tersebut. Selanjutnya menetapkan solusi untuk kebijakan dari setiap alternatif yang ada.

\subsubsection{Simple Additive Weighting (SAW)}

Konsep dasar dalam metode SAW adalah mencari penilaian terbobot dari rating kinerja pada setiap alternatif pada semua atribut [1]. Metode ini membutuhkan sebuah proses dalam normalisasi matriks keputusan (X) ke suatu skala yang dapat membandingkan dengan semua rating alternatif yang ada.

$$
r_{i j}=\left\{\begin{array}{l}
\frac{X_{i j}}{M a x X_{i j}} \rightarrow \text { Jika jadalah atribut keuntungan } \\
\frac{\text { Min } X_{i j}}{X_{i j}} \rightarrow \text { Jika jadalah atibut biaya }(\text { Cost })
\end{array}\right.
$$

Keterangan :

$\mathrm{r}_{\mathrm{ij}}=$ nilai rating kriteria ternormalisasi

$\mathrm{x}_{\mathrm{ij}}=$ nilai atribut yang dimiliki dari setiap kriteria

$\max \mathrm{x}_{\mathrm{ij}}=$ nilai terbesar dari setiap kriteria

$\min x_{\mathrm{ij}}=$ nilai terkecil dari setiap kriteria

benefit $=$ jika nilai terbesar adalah terbaik

$\operatorname{cost}=$ jika nilai terkecil adalah terbaik
Dari hasil rating kinerja yang telah ternormalisasi $\left(r_{i j}\right)$ dari alternatif $A_{i}$ pada atribut cj; $I=1,2, \ldots, m$ dan $j=1,2, \ldots, n$. Dengan ini nilai preferensi untuk setiap alternatif $\left(\mathrm{V}_{\mathrm{i}}\right)$ adalah sebagai berikut:

$$
V_{i}=\sum_{j=1}^{n} w_{j} r_{i j}
$$

Keterangan :

$\mathrm{V}_{\mathrm{i}}=$ rating setiap alternatif

$\mathrm{W}_{\mathrm{j}}=$ nilai bobot dari setiap kriteria

$\mathrm{R}_{\mathrm{ij}}=$ nilai rating kinerja ternormalisasi nilai $\mathrm{V}_{\mathrm{i}}$ yang lebih besar mengindikasikan bahwa alternatif $\mathrm{A}_{\mathrm{i}}$ lebih terpilih.

\subsubsection{PHP}

PHP merupakan bahasa pemrograman yang berbasis di web yang menjalankan fungsi sebagai backend website. PHP memiliki banyak framework salah satunya adalah Laravel. Laravel memiliki sifat open source dan memiliki konsep MVC (Model-View-Controller) [15]. Laravel merupakan sebuah pengembangan dari PHP yang dirancang untuk meningkatkan kualitas perangkat lunak, menghemat waktu, mengurangi biaya pengembangan awal dan biaya pemeliharaan [16].

\subsubsection{Website}

Website merupakan sebuah kumpulan halaman yang digunakan untuk menampilkan informasi berupa teks, gambar, animasi, suara atau gabungan dari semua baik secara dinamis maupun statis yang dapat saling terkait satu sama lainnya [17].

\section{Metodologi \\ 3.1 Metode Pembuatan Aplikasi}

Bagian Metode dalam pembuatan aplikasi yang diterapkan adalah model waterfall. Model waterfall merupakan metode SDLC (Software Development Life Cycle) yang paling sederhana. Model ini sangat cocok untuk pengembangan dengan spesifikasi yang tidak berubah-ubah. Model waterfall sering disebut dengan model sekuensial linier [18]. 
Pada gambar 1 merupakan tahapan pengembangan dalam model waterfall. Berikut adalah tahapan dalam model waterfall.

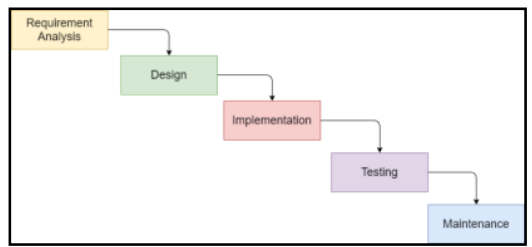

Gambar 1. SDLC Waterfall

\section{Requirement Analysis}

Tahap ini adalah tahapan paling awal sebelum melakukan pembuatan aplikasi. Di tahap ini penulis melakukan observasi ke salah satu sekolah dasar. Penulis melakukan wawancara terkait pengelolaan data penilaian siswa kepada salah satu pihak sekolah. Setelah mendapatkan informasi, penulis melakukan analisa dari hasil wawancara tersebut dan menentukan kebutuhan yang akan dikerjakan sesuai dengan hasil wawancara terhadap pihak sekolah.

2. Design

Pada tahap ini penulis melakukan perancangan alur data pada sistem yang dikembangkan dalam bentuk ERD. Perancangan ERD didasarkan kepada hasil analisa kebutuhan yang sudah dilakukan oleh penulis.

\section{Implementation}

Pada tahap ini merupakan implementasi dari hasil rancangan yang dibuat penulis. Implementasi ini diterapkan ke dalam phpMyAdmin sebagai pembuatan database. Setelah itu pembuatan aplikasi menggunakan Visual Studio Code sebagai text editor dan menggunakan bahasa pemrograman PHP dengan framework Laravel, serta menerapkan sistem pendukung keputusan dengan metode SAW ke dalam sistem.

\section{5. $\quad$ Testing}

Setelah selesai tahap implementasi, selanjutnya dilakukan pengujian terhadap sistem dan sistem pendukung keputusan yang telah dibuat. Tujuan dari testing adalah untuk mengurangi kesalahan dalam sistem dan memastikan fungsi-fungsi yang ada di dalam sistem benar-benar berjalan dengan lancar.

\section{Maintenance}

Di tahap ini akan dilakukan perbaikan permasalahan jika ditemukan. Tahapan ini dilakukan di sekolah sebagai implementasi dari sistem tersebut dan juga tahapan ini sebagai sarana umpan balik dari pihak sekolah agar sistem ini bisa bekerja dengan maksimal.

\subsection{Metode Perancangan Sistem SAW}

Dalam metode ini terdapat beberapa tahapan untuk menentukan dalam metode SAW. berikut adalah beberapa tahapannya:

1. Penentuan Kriteria

Dalam penelitian ini. Kriteria diambil berdasarkan hasil wawancara terhadap client. Kriteria yang dihasilkan kesepakatan antara peneliti dengan client ada 3 kriteria yang akan diterapkan. Kriteria tersebut yaitu dari penilaian tugas, UTS dan UAS

2. Penentuan Bobot

Penentuan bobot didapatkan dari hasil wawancara dengan pihak client. Hasil kesepakatan antara peneliti dengan client yaitu bobot untuk tugas sebesar $20 \%$, untuk bobot UTS sebesar $40 \%$ dan bobot UAS sebesar $40 \%$.

3. Menentukan setiap alternatif pada kriteria. Alternatif yang dipakai dalam penelitian ini adalah dari mata pelajaran. Dan setiap jenjang kelas mata pelajaran selalu berubah dan dalam penelitian ini, alternatif bisa di tambahkan sesuai dengan keinginan client

4. Normalisasi matriks dari setiap alternatif pada kriteria.

5. Mencari hasil peringkat alternatif dari hasil normalisasi matriks.

\section{Pembahasan}

\subsection{Entity Relationship Diagram (ERD)}

Dalam gambar 2 merupakan alur data ERD yang kumpulan tabel tersebut diproses ke 
dalam sistem penentuan penilaian yang telah dipasangkan sistem pendukung keputusan dengan metode SAW.

Dalam gambar 2, dapat diketahui bahwa terdapat 8 entitas yang saling berhubungan. Berikut adalah rincian dari relasi yang ada pada ERD tersebut:

1. Entitas user memiliki disjoint dengan 3 entitas yaitu entitas siswa, wali kelas dan admin

2. Entitas kelas dengan entitas siswa memiliki kardinalitas berupa one to many. Di mana entitas kelas memiliki banyak entitas siswa, namun entitas siswa hanya dimiliki satu entitas kelas.

3. Entitas wali_kelas dengan entitas kelas memiliki kardinalitas one to one. Di mana entitas wali kelas hanya memiliki satu entitas kelas, Sedangkan entitas kelas hanya dimiliki satu wali kelas.

4. Entitas wali_kelas dengan entitas penilaian_siswa memiliki kardinalitas one to many. Di mana entitas wali_kelas menginput banyak penilaian_siswa, namun entitas penilaian siswa hanya diinput satu entitas wali kelas.

5. Entitas mata_pelajaran dengan entitas penilaian siswa memiliki kardinalitas one to many. Di mana entitas mata pelajaran memiliki banyak entitas penilaian siswa, namun entitas penilaian_siswa hanya dimiliki satu entitas mata_pelajaran.

6. Entitas penilaian_siswa dengan entitas tugas memiliki kardinalitas one to many. Di mana entitas penilaian_siswa mendetailkan banyak entitas tugas, namun entitas tugas hanya didetailkan satu entitas penilaian siswa.

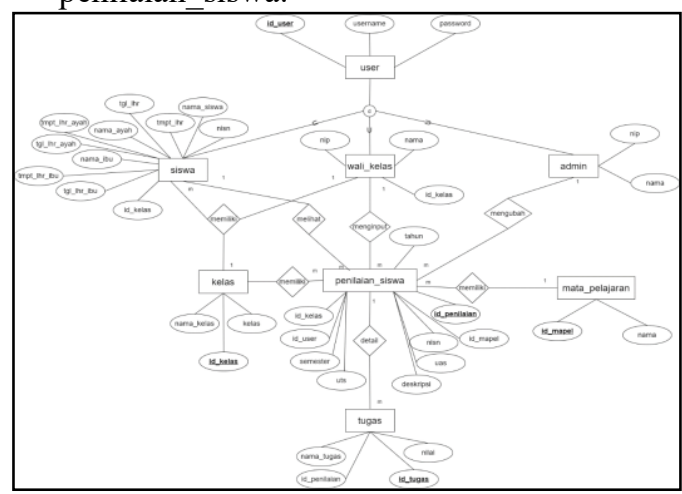

http://ejournal.upbatam.ac.id/index.php/cbis
Gambar 2. ERD Sistem Penilaian Siswa

\subsection{Implementasi}

\subsubsection{Tampilan Halaman Login}

Di halaman ini adalah tampilan awal ketika pertama kali dibuat. Di website ini terdapat 3 akses yaitu admin, wali kelas dan siswa. Ketika diisi kedua textbox dan klik button masuk, maka akan melakukan proses penyaringan akses jika kedua textbox tersebut sesuai, maka selanjutnya proses pemeriksaan hak akses untuk bisa melanjutkan halaman selanjutnya.

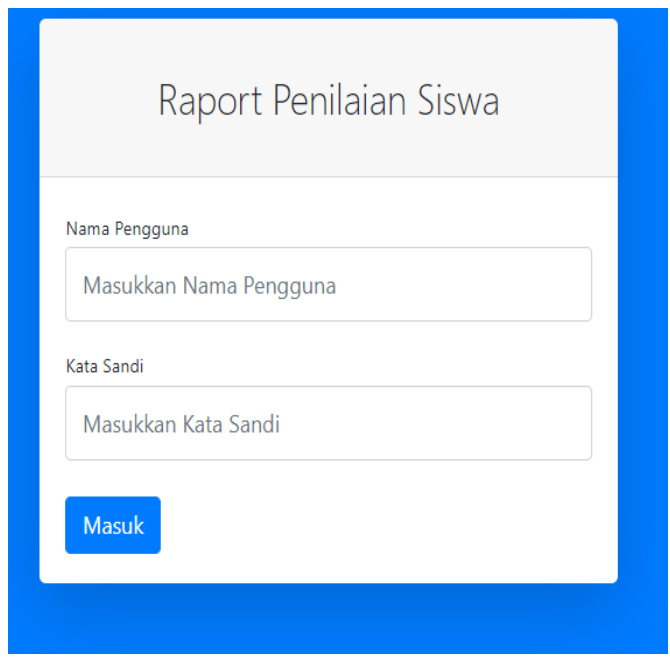

Gambar 3. Implementasi Halaman Login

\subsubsection{Tampilan Halaman Rapor Siswa}

Ketika di awal masuk halaman rapor siswa, tabel data penilaian siswa tidak muncul. Tabel data penilaian siswa muncul ketika pengguna melakukan pencarian data. Halaman rapor siswa hanya dapat diakses oleh wali kelas dan admin.

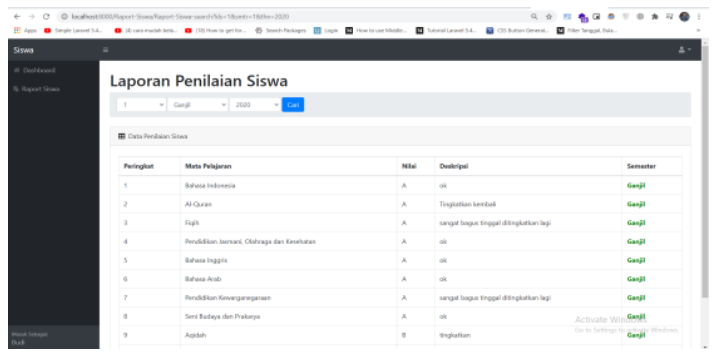

Gambar 4. Implementasi Halaman Rapor Siswa

\subsubsection{Tampilan Halaman Biodata Siswa}

Pada halaman ini, wali kelas hanya bisa mengubah data siswa. Halaman biodata siswa 
hanya dapat diakses oleh wali kelas dan admin. Perbedaan biodata siswa di halaman admin dengan wali kelas adalah admin bisa menghapus data siswa, jika siswa tersebut belum diinput nilai sedangkan wali kelas sebaliknya.

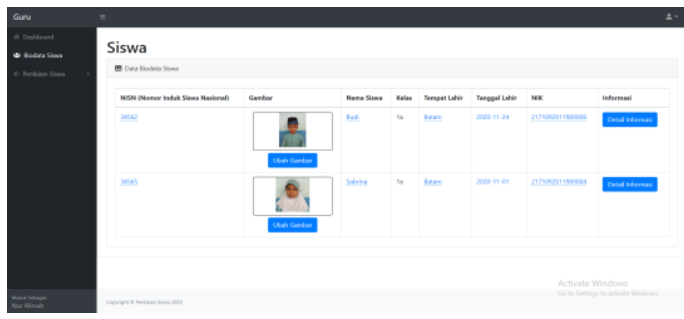

Gambar 5. Implementasi Halaman Biodata Siswa

\subsubsection{Tampilan Halaman Input dan Edit Nilai}

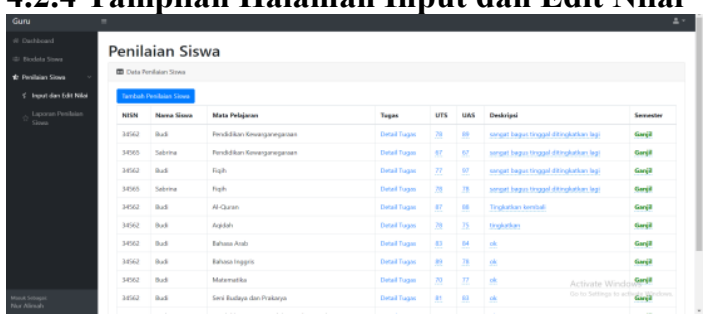

Gambar 6. Implementasi Halaman Input dan Edit Nilai

Di halaman ini data muncul berdasarkan kelas yang dipegang oleh wali kelas yang sama dengan siswa. Halaman input dan edit nilai hanya dapat diakses oleh wali kelas.

\subsubsection{Tampilan Halaman Laporan Penilaian} Siswa

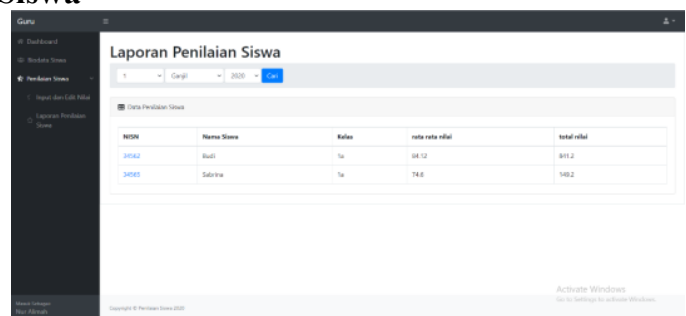

Gambar 7. Implementasi Halaman Laporan Penilaian Siswa 


\section{Penilaian Siswa}

円 Data Penilaian Siswa
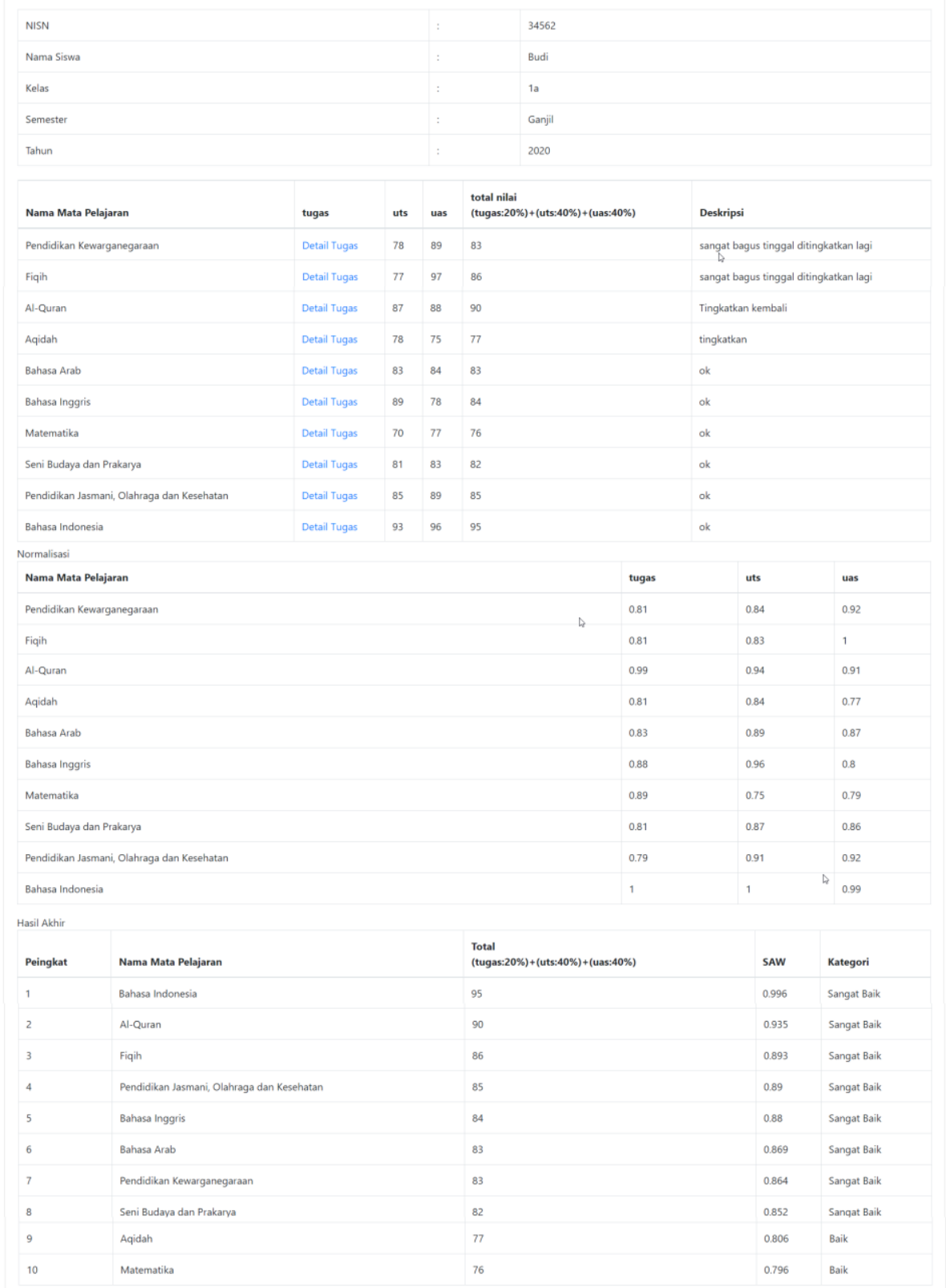

Gambar 8. Implementasi Halaman Detail Laporan Penilaian Siswa

Di gambar 7, pada awal masuk di halaman ini data penilaian siswa tidak muncul dan akan muncul ketika data pencarian tersebut diisi. Ketika di klik nomor NISN di gambar 7, maka akan muncul detail nilai seperti gambar 8. Di gambar 7 dan 8 hanya dapat diakses oleh admin dan wali kelas. Untuk halaman ini, perbedaan antara admin dengan wali kelas yaitu data dan 
bagian detail admin bisa edit nilai. Data yang ditampilkan oleh wali kelas hanya nilai yang pernah diisi oleh wali kelas sedangkan admin yang ditampilkan adalah keseluruhan nilai siswa.

\subsubsection{Tampilan Halaman Wali Kelas}

Pada gambar 9 digunakan untuk membuat akun hak akses wali kelas. Di halaman ini terdapat fungsi untuk mengubah, menambahkan dan menonaktifkan akun. Halaman wali kelas ini hanya dapat diakses oleh admin.

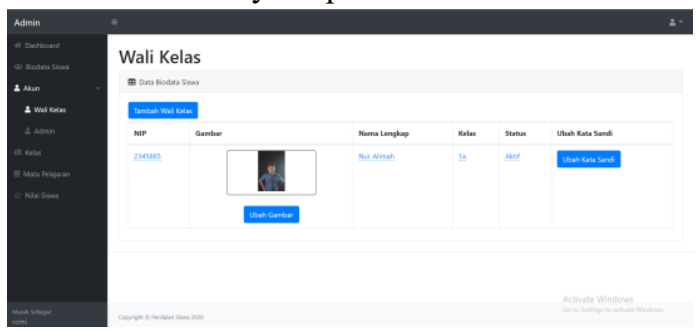

Gambar 9. Implementasi Halaman Wali Kelas

\subsubsection{Tampilan Halaman Admin}

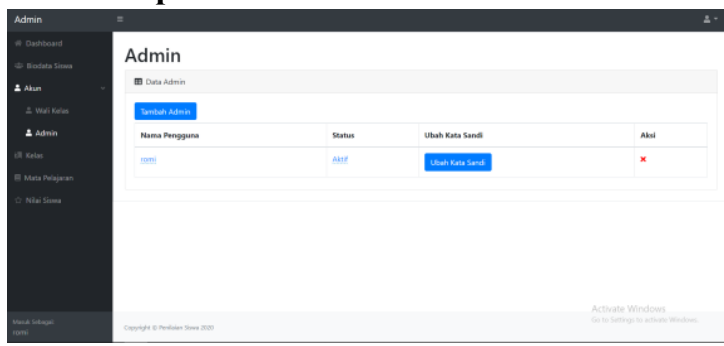

Gambar 10. Implementasi Halaman Admin

Pada gambar 10 digunakan untuk membuat akun untuk hak akses admin. Halaman admin ini hanya dapat diakses oleh admin. Di halaman ini terdapat fungsi untuk mengubah, menghapus, menambahkan serta bisa menonaktifkan akun admin.

\subsubsection{Tampilan Halaman Kelas}

Pada gambar 11 merupakan tampilan halaman kelas. Di halaman ini terdapat fungsi untuk menambahkan, mengubah serta menonaktifkan kelas. Halaman kelas hanya dapat diakses oleh admin.

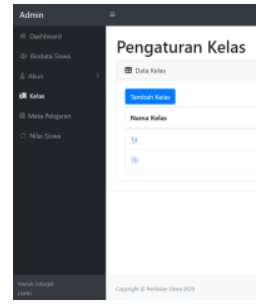

Gambar 11. Implementasi Halaman Kelas

\subsubsection{Tampilan Halaman Mata Pelajaran}

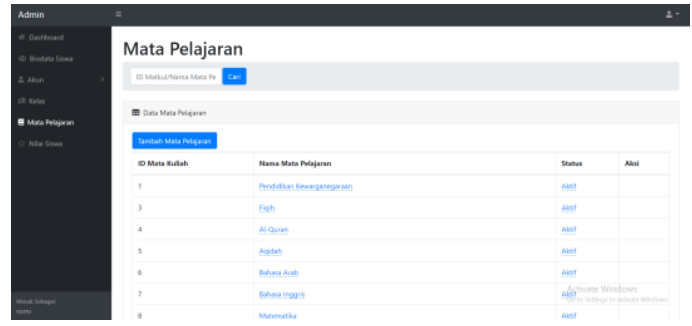

Gambar 12. Implementasi Halaman Mata Pelajaran

Pada gambar 12 adalah tampilan halaman mata pelajaran. Di halaman ini terdapat fungsi pencarian berdasarkan id atau nama mata pelajaran, menambahkan data dan mengubah data. Sedangkan untuk penghapusan data hanya bisa dilakukan jika mata pelajaran tersebut tidak ada dimasukkan ke dalam nilai siswa. Halaman mata pelajaran ini hanya dapat diakses oleh admin.

\subsection{Hasil Pengujian Perhitungan SAW}

Berikut adalah perhitungan manual dalam pembuktian metode SAW dengan gambar 8.

Tabel 1. Kriteria

\begin{tabular}{lll}
\hline $\begin{array}{l}\text { Kode } \\
\text { Kriteria }\end{array}$ & Keterangan & Bobot \\
\hline C1 & Tugas & $20 \%$ \\
C2 & Ujian Tengah Semester & $40 \%$ \\
C3 & Ujian Akhir Semester & $40 \%$ \\
\hline
\end{tabular}

Dari kriteria di atas, ada tahapan selanjutnya yaitu data alternatif. Berikut adalah data alternatif tersebut.

Tabel 2. Data Alternatif

\begin{tabular}{ll}
\hline Kode & Keterangan \\
\hline A1 & Pendidikan Kewarganegaraan \\
A2 & Fiqih \\
A3 & Al-Quran \\
A4 & Aqidah \\
A5 & Bahasa Arab
\end{tabular}




\begin{tabular}{lll} 
A6 & Bahasa Inggris \\
A7 & Matematika \\
A8 & Seni Budaya dan Prakarya \\
A9 & $\begin{array}{l}\text { Pendidikan Jasmani, Olahraga dan } \\
\text { Kesehatan }\end{array}$ \\
A10 & Bahasa Indonesia \\
\hline
\end{tabular}

Setelah mendapatkan hasil dari data alternatif, selanjutnya menampilkan data nilai masing-masing mata pelajaran.

Tabel 3. Data Nilai Setiap Mata Pelajaran

\begin{tabular}{llll}
\hline Alternatif & \multicolumn{3}{c}{ Kriteria } \\
\cline { 2 - 4 } & \multicolumn{2}{c}{$\mathrm{C} 1$} & \multicolumn{2}{c}{$\mathrm{C} 2$} & $\mathrm{C} 3$ \\
\hline A1 & 80 & 78 & 89 \\
A2 & 80 & 77 & 97 \\
A3 & 98 & 87 & 88 \\
A4 & 80 & 78 & 75 \\
A5 & 82 & 83 & 84 \\
A6 & 87 & 89 & 78 \\
A7 & 88 & 70 & 77 \\
A8 & 80 & 81 & 83 \\
A9 & 78 & 85 & 89 \\
A10 & 99 & 93 & 96 \\
\hline
\end{tabular}

Setelah mendapatkan data penilaian masing-masing mata pelajaran, selanjutnya data dari tabel 3 diolah ke dalam normalisasi matriks. Rumus yang digunakan adalah

$$
r_{i j}=\frac{X_{i j}}{\max _{i} X_{i j}}
$$

Tabel 4. Perhitungan Masing-Masing Nilai Mata

\begin{tabular}{lrrr}
\multicolumn{4}{c}{ Pelajaran } \\
\hline \multirow{2}{*}{ Alternatif } & \multicolumn{3}{c}{ Kriteria } \\
\cline { 2 - 4 } & $\mathrm{C} 1$ & $\mathrm{C} 2$ & $\mathrm{C} 3$ \\
\hline A1 & $80 / 99$ & $78 / 93$ & $89 / 97$ \\
A2 & $80 / 99$ & $77 / 93$ & $97 / 97$ \\
A3 & $98 / 99$ & $87 / 93$ & $88 / 97$ \\
A4 & $80 / 99$ & $78 / 93$ & $75 / 97$ \\
A5 & $82 / 99$ & $83 / 93$ & $84 / 97$ \\
A6 & $87 / 99$ & $89 / 93$ & $78 / 97$ \\
A7 & $88 / 99$ & $70 / 93$ & $77 / 97$ \\
A8 & $80 / 99$ & $81 / 93$ & $83 / 97$ \\
A9 & $78 / 99$ & $85 / 93$ & $89 / 97$ \\
A10 & $99 / 99$ & $93 / 93$ & $96 / 97$ \\
\hline
\end{tabular}

Tabel 5. Hasil Perhitungan Masing-Masing Nilai Mata Pelajaran

\begin{tabular}{cccc}
\hline \multirow{2}{*}{ Alternatif } & \multicolumn{3}{c}{ Kriteria } \\
\cline { 2 - 4 } & $\mathrm{C} 1$ & $\mathrm{C} 2$ & $\mathrm{C} 3$ \\
\hline
\end{tabular}

http://ejournal.upbatam.ac.id/index.php/cbis

\begin{tabular}{llll}
\hline A1 & 0.81 & 0.84 & 0.92 \\
A2 & 0.81 & 0.83 & 1 \\
A3 & 0.99 & 0.94 & 0.91 \\
A4 & 0.81 & 0.84 & 0.77 \\
A5 & 0.83 & 0.89 & 0.87 \\
A6 & 0.88 & 0.96 & 0.80 \\
A7 & 0.89 & 0.75 & 0.79 \\
A8 & 0.81 & 0.87 & 0.86 \\
A9 & 0.79 & 0.91 & 0.92 \\
A10 & 1 & 1 & 0.99 \\
\hline
\end{tabular}

Setelah data dinormalisasi, selanjutnya melakukan pemeringkatan dari hasil normalisasi dengan bobot yang ada di tabel 1 .

Tabel 6. Perhitungan Pemeringkatan MasingMasing Mata Pelajaran

\begin{tabular}{|c|c|}
\hline $\begin{array}{l}\text { Alternat } \\
\text { if }\end{array}$ & Total SAW \\
\hline A1 & $\begin{array}{l}((0.81 * 20 \%)+(0.84 * 40 \%)+(0.92 * 4 \\
0 \%))\end{array}$ \\
\hline $\mathrm{A} 2$ & $\begin{array}{l}((0.81 * 20 \%)+(0.83 * 40 \%)+(1 * 40 \% \\
))\end{array}$ \\
\hline A3 & $\begin{array}{l}((0.99 * 20 \%)+(0.94 * 40 \%)+(0.91 * 4 \\
0 \%))\end{array}$ \\
\hline A4 & $\begin{array}{l}((0.81 * 20 \%)+(0.84 * 40 \%)+(0.77 * 4 \\
0 \%))\end{array}$ \\
\hline A5 & $\begin{array}{l}((0.83 * 20 \%)+(0.89 * 40 \%)+(0.87 * 4 \\
0 \%))\end{array}$ \\
\hline A6 & $\begin{array}{l}((0.88 * 20 \%)+(0.96 * 40 \%)+(0.80 * 4 \\
0 \%))\end{array}$ \\
\hline A7 & $\begin{array}{l}((0.89 * 20 \%)+(0.75 * 40 \%)+(0.79 * 4 \\
0 \%))\end{array}$ \\
\hline A 8 & $\begin{array}{l}((0.81 * 20 \%)+(0.87 * 40 \%)+(0.86 * 4 \\
0 \%))\end{array}$ \\
\hline A9 & $\begin{array}{l}((0.79 * 20 \%)+(0.91 * 40 \%)+(0.92 * 4 \\
0 \%))\end{array}$ \\
\hline A10 & $((1 * 20 \%)+(1 * 40 \%)+(0.99 * 40 \%))$ \\
\hline
\end{tabular}

Tabel 6. Hasil Perhitungan Pemeringkatan Masing-Masing Mata Pelajaran

\begin{tabular}{lll}
\hline Alternatif & Total SAW & Peringkat \\
\hline A1 & 0.864 & 7 \\
A2 & 0.893 & 3 \\
A3 & 0.935 & 2 \\
A4 & 0.806 & 9 \\
A5 & 0.869 & 6 \\
A6 & 0.880 & 5 \\
A7 & 0.796 & 10 \\
A8 & 0.852 & 8 \\
A9 & 0.890 & 4 \\
A10 & 0.996 & 1 \\
\hline
\end{tabular}


Dari hasil perhitungan manual dengan gambar 8 hasilnya sama. Dengan begitu dapat disimpulkan bahwasanya penerapan metode SAW ke dalam sistem penilaian siswa telah berhasil dilakukan.

\subsection{Hasil Pengujian Sistem}

Tabel 7. Hasil Pengujian Coba Sistem

\begin{tabular}{ll}
\hline \multicolumn{1}{c}{ Hasil yang Diharapkan } & Status \\
\hline - & Pengguna berhasil login muncul \\
& halaman dashboard \\
- & Pengguna gagal login, Kembali Berhasil \\
& ke halaman login dan muncul \\
& notifikasi gagal login
\end{tabular}

Hak akses siswa

- Melakukan pencarian berdasarkan kelas, semester dan Berhasil tahun di menu rapor siswa

Hak akses wali kelas

- Melakukan pencarian berdasarkan kelas, semester, dan tahun di menu laporan penilaian siswa

Hak akses admin

- Melakukan pencarian berdasarkan NISN atau nama siswa dan kelas di menu biodata siswa

- Melakukan pencarian berdasarkan id mata pelajaran atau nama mata pelajaran di menu mata pelajaran

- Melakukan pencarian berdasarkan NISN atau nama siswa dan kelas di menu biodata siswa

- Melakukan pencarian berdasarkan kelas, semester dan tahun di menu nilai siswa

Hak akses wali kelas

- Mengisi nama siswa, mata pelajaran, semester, tugas, UTS, Berhasil UAS dan deskripsi di menu input dan edit nilai

Berhasil
Hak akses admin

- Mengisi gambar siswa, NISN, nama lengkap, kelas, tempat lahir, tanggal lahir, NIK, nama ayah, pekerjaan ayah, tempat lahir ayah, tanggal lahir ayah, nama ibu, pekerjaan ibu, tempat lahir ibu dan tanggal lahir ibu di menu biodata siswa

- Mengisi foto wali kelas, NIP, nama lengkap dan kelas di menu wali kelas

- Mengisi nama pengguna dan kata sandi di menu admin

- Mengisi nama kelas, kelas dan status di menu kelas

- Mengisi nama mata pelajaran dan status di menu mata pelajaran

\section{Berhasil Hak akses wali kelas}

- Mengubah data NISN, foto siswa, nama siswa, kelas, tempat lahir, tanggal lahir, NIK, nama ayah, pekerjaan ayah, tempat lahir ayah, tanggal lahir ayah, nama ibu, pekerjaan ibu, tempat lahir ibu dan tanggal lahir ibu di menu biodata siswa

- Mengubah nilai tugas, UTS, UAS, deskripsi dan semester di menu input dan edit nilai

Hak akses admin

- Mengubah data NISN, foto siswa, nama siswa, kelas, tempat lahir, tanggal lahir, NIK, nama ayah, pekerjaan ayah, tempat lahir ayah, tanggal lahir ayah, nama ibu, pekerjaan ibu, tempat lahir ibu dan tanggal lahir ibu di menu biodata siswa

- Mengubah data NIP, foto wali kelas, nama lengkap, kelas, status dan ubah kata sandi di menu wali kelas
Berhasil

Berhasil

Berhasil 
- Mengubah nama pengguna, status dan kata sandi untuk menu admin

- Mengubah data nama kelas, kelas dan status di menu kelas

- Mengubah data nama mata pelajaran dan status di menu mata pelajaran

- Mengubah data nilai tugas, UTS dan UAS di menu nilai siswa

Hak akses admin

- Menghapus data di menu biodata siswa

Berhasil

- Menghapus data di menu admin

- Menghapus data di menu mata pelajaran

Dari hasil tabel 7 menunjukkan setiap fungsi yang ada di web berhasil dan berjalan dengan lancar.

\section{Kesimpulan}

Dari hasil implementasi metode SAW ke dalam sistem penilaian siswa, sistem ini dibuat dengan framework Laravel dan bahasa pemrograman PHP. Dengan diterapkan metode SAW, wali kelas dan orang tua bisa mempertimbangkan dan mengevaluasi mata pelajaran. Hasil perhitungan metode SAW sebagai peringkat nilai tertinggi ke terendah untuk mata pelajaran. Metode SAW memiliki kriteria yaitu nilai UTS, nilai UAS dan rata-rata nilai tugas yang diterapkan ke dalam sistem. Sistem pendukung keputusan telah berhasil membantu pihak sekolah sebagai bahan pertimbangan untuk kebijakan pembelajaran terutama di mata pelajaran yang perlu ditingkatkan bagi pihak sekolah dan orang tua.

\section{Ucapan Terima Kasih}

Terima kasih kepada Tony Wibowo S.Kom, MMSI selaku Kepala Program Studi Sistem Informasi Universitas Internasional Batam, Sekolah Madrasah Ibtidayah Negeri Bengkong yang telah memberikan kesempatan penulis untuk mengembangkan penelitian ini dan Calvin Chin yang telah memberikan masukan dan saran dalam penelitian ini.

\section{Daftar Pustaka}

[1] E. Susanti, "Sistem Pendukung Keputusan Penentuan Siswa Berprestasi pada SMA Xaverius Pringsewu Menggunakan Metode SAW," vol. 3, no. $1,2017$.

[2] M. Muthohir and A. Zainudin, "Penerapan Metode Simple Additive Weight (SAW) pada Sistem Informasi Pemilihan Jurusan Berbasis Decision Support System," J. Smart COMP, vol. 7, no. 1, 2018.

[3] A. Setiadi, Yunita, and A. R. Ningsih, "Penerapan Metode Simple Additive Weighting(SAW) Untuk Pemilihan Siswa Terbaik," J. Sisfokom (Sistem Inf. dan Komputer), vol. 7, no. 2, 2018.

[4] A. D. Susanti, M. Muslihudin, and S. Hartati, "Sistem Pendukung Keputusan Perankingan Calon Siswa Baru Jalur Undangan Menggunakan Simple Additive Weighting (Studi Kasus: Smk Bumi Nusantara Wonosobo)," Semin. Nas. Teknol. Inf. dan Multimed. 2017, vol. 5, no. 1, pp. 37-42, 2017.

[5] H. Agung and Ricky, "Aplikasi Sistem Pendukung Keputusan Untuk Pemilihan Siswa Teladan Menggunakan Metode TOPSIS," J. Ilm. FIFO, vol. 8, no. 2, 2016.

[6] W. Sari, A. M. Rifki, and M. Karmila, "Analisa Kebijakan Pendidikan Tekait Implementasi Pembelajaran Jarak Jauh pada Masa Darurat COVID 19," $J$. MAPPESONA, 2020.

[7] D. P. Sari, "SPK Seleksi Penerimaan Guru Baru pada Yayasan Garis Pena Payakumbuh Menggunakan Metode SAW," J-Click, vol. 6, no. 2, pp. 201207, 2019

[8] M. F. Asnawi and M. A. M. Baihaqy, "Implementasi Metode Simple Additive Weigth (SAW) pada Sistem Pendukung Keputusan Penentuan Dosen Berprestasi," J. Penelit. dan Pengabdi. Kpd. Masy. UNSIQ, vol. 6, no. 3, pp. 198 205, 2019.

[9] E. Ismanto and N. Effendi, "Sistem 
Pendukung Keputusan Penerimaan Karyawan dengan Metode Simple Additive Weighting (SAW)," SATIN Sains dan Teknol. Inf., vol. 3, no. 1, p. 1, 2017.

[10] J. Simarmata, T. Limbong, M. Aritonang, and Sriadhi, "Sistem Pendukung Keputusan Pemilihan Guru Bidang Studi Komputer Menggunakan Metode Simple Additive Weighting (Saw)," Comput. Eng. Sci. Syst. J., vol. 3, no. 2, pp. 186-190, 2018.

[11] S. Aisyah, "Aplikasi Sistem Pendukung Keputusan Analisis Kelayakan Pemberian Kredit Menggunakan Metode SAW pada Perusahaan Leasing," $J$. Teknovasi, vol. 06, no. 1, pp. 1-16, 2019.

[12] A. A. Chamid and A. C. Murti, "Kombinasi Metode AHP dan TOPSIS pada Sistem Pendukung Keputusan," Prosiding SNATIF, vol. 4. pp. 115-119, 2017.

[13] S. Barus, V. M. Sitorus, D. Napitupulu, Mesran, and Supiyandi, "Sistem Pendukung Keputusan Pengangkatan Guru Tetap Menerapkan Metode Weight Aggregated Sum Product Assesment (WASPAS)," J. Media Inform. Budidarma, vol. 2, no. 2, pp. 10-15, 2018.

[14] A. P. Windarto, "Implementasi Metode
TOPSIS dan SAW Dalam Memberikan Reward Pelanggan," Klik - Kumpul. J. Ilmu Komput., vol. 4, no. 1, pp. 88-101, 2017.

[15] D. Mediana and A. I. Nurhidayat, "Rancang Bangun Aplikasi Helpdesk (ADesk) Berbasis Web Menggunakan Framework Laravel ( Studi Kasus di PDAM Surya Sembada Kota Surabaya )," J. Manaj. Inform., vol. 8, no. 2, pp. 75-81, 2018.

[16] B. Hermanto, M. Yusman, and Nagara, "Sistem Informasi Manajemen Keuangan pada PT. Hulu Balang Mandiri Menggunakan Framework Laravel," J. Komputasi, vol. 7, no. 1, pp. 17-26, 2019.

[17] J. Sundari, "Sistem Informasi Pelayanan Puskesmas Berbasis Web," IJSE Indones. J. Softw. Eng., vol. 2, no. 1, pp. 44-49, 2016.

[18] T. Nurhaeni, I. Handayani, R. A. Nurcahya, and A. Rifaldi, "Sistem Penilaian Sidang Komprehensif Tugas Akhir Skripsi dan Tesis Berbasis Yii Framework Menggunakan Business Intelligence Methodology," Technomedia J., vol. 5, no. 1, pp. 82-96, 2020. 